\title{
Chapter 7 \\ Site-Directed Mutagenesis in Barley by \\ Expression of TALE Nuclease \\ in Embryogenic Pollen
}

\author{
Maia Gurushidze, Stefan Hiekel, Ingrid Otto, Götz Hensel, \\ and Jochen Kumlehn
}

\begin{abstract}
In this chapter, a detailed protocol for the induction of targeted mutations in barley using customized transcription activator-like effector nucleases (TALENs) is provided. As explant for the introduction of TALEN expression constructs, embryogenic pollen cultures are used which consist primarily of haploid cells able to be converted via pollen embryogenesis and genome duplication into fertile doubled haploid plants. Thanks to the haploid nature of these target cells, a mutation induced by TALE nucleases in just one $g f p$ allele can be readily detected in vitro and thus genetically fixed primary mutant plants obtained in one generation.
\end{abstract}

Keywords Customizable endonuclease - Doubled haploids • Embryogenesis • Homozygosity $\bullet$ Microspore $\bullet$ Targeted knockout

\subsection{Introduction}

\subsubsection{Site-Directed Mutagenesis in Plants}

The continuously growing demand of the world population for food is a tremendous challenge for modern agriculture, plant breeding, and biotechnology (Griggs et al. 2013). To rapidly produce new plant varieties with improved gene variants and traits, more efficient, flexible, and reliable methods such as site-directed mutagenesis are needed. In addition, these techniques will also have a big impact on basic science by helping to further investigate gene function and regulation.

Site-directed mutagenesis enables researchers to alter the DNA sequence at a predefined location in the genome of a plant cell. Such mutations can be generated by the use of customized endonucleases for target sequence-specific double-strand

M. Gurushidze • S. Hiekel • I. Otto • G. Hensel • J. Kumlehn ( $₫)$

Plant Reproductive Biology, Leibniz Institute of Plant Genetics and Crop Plant Research (IPK)

Gatersleben, Corrensstrasse 3, 06466 Seeland, OT Gatersleben, Germany

e-mail: kumlehn@ipk-gatersleben.de 
break (DSB) induction. The repair of DSBs via nonhomologous end-joining is error-prone to some extent and therefore can lead to nucleotide deletions or insertions (indels) at the breakage site (Waterworth et al. 2011). Depending on the type of mutation, this can result in functional modification, complete disruption of gene function, or removal of whole gene clusters from the plant genome.

For application of this technique in model and crop plant species, the following customizable endonuclease platforms with different benefits and drawbacks are available: meganucleases, zinc-finger nucleases (ZFNs), transcription activator-like effector nucleases (TALENs), and RNA-guided endonucleases (RGENs); the latter derive from a clustered regularly interspaced short palindromic repeats/CRISPRassociated (CRISPR/Cas) microbial defense system [reviewed in Fichtner et al. (2014)].

TALENs are created by the fusion of a customized TALE DNA-binding domain (DBD) and the FokI restriction-endonuclease domain (FokI-R) (Christian et al. 2010). Primarily, a TALE-DBD from plant pathogenic bacteria Xanthomonas sp. consists of a variable number of nearly identical amino acid repeats. Each repeat has a length of 33-35 amino acids and binds preferentially to a certain nucleotide of the target DNA sequence (Boch et al. 2009; Moscou and Bogdanove 2009). Different binding specificity of distinct repeats can be explained by variations in amino acids 12 and 13, which are therefore called repeat variable diresidues (RVDs). The amino acid pairs most commonly used in RVDs of TALE-DBDs are NI (binding to adenine), NG (thymine), NN (guanine), and HD (cytosine). Given the opportunity of rearrangement of these repeats, it is possible to assemble a TALE-DBD for virtually any DNA target sequence of choice.

Such customized TALEN-DBD in combination with the $25 \mathrm{kDa}$ FokI-R domain, with the latter not having any own DNA-binding specificity (Li et al. 1992), TALENs represent a universal tool for DSB induction. However, FokI-R needs to form dimers to be catalytically active (Bitinaite et al. 1998). Therefore, two TALEN subunits binding to the desired target sequence in inverse orientation to each other are required. This obligatory dimerization decreases the probability for off-target mutations but also doubles the effort to produce an effective TALEN. TALENcoding DNA subunits can be highly efficiently assembled via Golden Gate cloning [e.g., Cermak et al. (2011)], PCR-based methods [e.g., Yang et al. (2013)], or FLASH assembly (Reyon et al. 2012).

TALENs are more cost effective and much easier to handle than zinc-finger nucleases (Beumer et al. 2013). Therefore, TALENs were successfully applied for site-directed mutagenesis in a number of model and crop plants like Arabidopsis (Christian et al. 2013), tobacco (Zhang et al. 2013), Nicotiana benthamiana (Mahfouz et al. 2011), Brachypodium distachyon (Shan et al. 2013), rice (Li et al. 2012), Brassica oleracea (Sun et al. 2013), soybean (Haun et al. 2014), wheat (Wang et al. 2014), maize (Liang et al. 2014), and barley (Wendt et al. 2013; Gurushidze et al. 2014). 


\subsubsection{Haploid Technology}

The development of immature barley pollen at the vacuolated microspore or early bicellular stage can be switched from the normal process of pollen maturation to an embryogenic pathway (Sunderland et al. 1979). The embryogenic structures formed can be regenerated into haploid and doubled haploid, instantly homozygous plants. As each doubled haploid individual originates from a different gametophytic cell produced via meiotic recombination, a population of doubled haploid plants represents a collection of genetically unique and fixed individuals. For this reason, haploid technology has become a valuable tool in functional genomics as well as in modern plant breeding. The genetic transformation of such haploid target cells followed by whole genome duplication opened up the unique opportunity to immediately generate plants homozygous with regards to the integrated transgene (Kumlehn et al. 2006). Similarly, the ability to mutagenize haploid cells in a targeted manner via expression of customized endonucleases (in the present case TALENs) permits the generation of instantly homozygous mutants, which makes this approach highly advantageous compared to previously published methods of gene targeting.

\subsection{Materials}

\subsubsection{Donor Plants}

1. The protocol is optimized for the winter type cultivar "Igri" released by Saatzucht Ackermann (Irlbach, Germany) in 1976. The target chosen in the example demonstrated here is the reporter gene encoding green fluorescent protein (GFP), since this provides a simple bioassay for knockout events. Accordingly, the transgenic "Igri" lines PV 89 and BPI 09 were used, which each carry a single copy of $g f p$ in homozygous state.

2. The germination substrate is a 3:1:2 mixture of garden mulch/sand/white and black peat (Substrate 2, Klasmann, Germany).

3. The soil substrate used after vernalization is a 2:2:1 mixture of compost/ Klasmann Substrate 2 and sand. Osmocote is used as a fertilizer containing $19 \% \mathrm{~N}, 6 \% \mathrm{P}$, and $12 \% \mathrm{~K}$.

4. Petuniensubstrat (Klasmann, Germany) is used for the acclimation of in vitro regenerants to grow on soil substrate. After vernalization, the substrate is refreshed as described above. 


\subsubsection{Stock Solutions and Culture Media}

\subsubsection{Stock Solutions}

1. Major mineral salts:

$\mathrm{K}$ macro $(20 \times)$ : $1.6 \mathrm{~g} / \mathrm{L} \mathrm{NH}_{4} \mathrm{NO}_{3}, 40.4 \mathrm{~g} / \mathrm{L} \mathrm{KNO}_{3}, 6.8 \mathrm{~g} / \mathrm{L} \mathrm{KH}_{2} \mathrm{PO}_{4}, 8.8 \mathrm{~g} / \mathrm{L}$ $\mathrm{CaCl}_{2} \cdot 2 \mathrm{H}_{2} \mathrm{O}, 4.9 \mathrm{~g} / \mathrm{L} \mathrm{MgSO} 4 \cdot 7 \mathrm{H}_{2} \mathrm{O}$.

K4N macro $(20 \times)$ : $6.4 \mathrm{~g} / \mathrm{L} \mathrm{NH}_{4} \mathrm{NO}_{3}, 72.8 \mathrm{~g} / \mathrm{L} \mathrm{KNO} \mathrm{KN}_{3}, 6.8 \mathrm{~g} / \mathrm{L} \mathrm{KH}_{2} \mathrm{PO}_{4}, 8.8 \mathrm{~g} / \mathrm{L}$ $\mathrm{CaCl}_{2} \cdot 2 \mathrm{H}_{2} \mathrm{O}, 4.9 \mathrm{~g} / \mathrm{L} \mathrm{MgSO}_{4} \cdot 7 \mathrm{H}_{2} \mathrm{O}$.

2. Trace mineral salts:

$\mathrm{K}$ micro $(1000 \times): 8.4 \mathrm{~g} / \mathrm{L} \mathrm{MnSO}_{4} \cdot \mathrm{H}_{2} \mathrm{O}, 3.1 \mathrm{~g} / \mathrm{L} \mathrm{H} \mathrm{BO}_{3}, 7.2 \mathrm{~g} / \mathrm{L} \mathrm{ZnSO} \cdot 7 \mathrm{H}_{2} \mathrm{O}$, $120 \mathrm{mg} / \mathrm{L} \mathrm{Na} \mathrm{MoO}_{4} \cdot 2 \mathrm{H}_{2} \mathrm{O}, 25 \mathrm{mg} / \mathrm{L} \mathrm{CuSO} \cdot 5 \mathrm{H}_{2} \mathrm{O}, 24 \mathrm{mg} / \mathrm{L} \mathrm{CoCl} \mathrm{Cl}_{2} \cdot 6 \mathrm{H}_{2} \mathrm{O}$, $170 \mathrm{mg} / \mathrm{L} \mathrm{KI}$.

3. Individual mineral salts:

Ferric sodium ethylenediaminetetraacetate (NaFeEDTA; $75 \mathrm{mM}, 27.5 \mathrm{~g} / \mathrm{L}$ ): filter-sterilized and stored at $4{ }^{\circ} \mathrm{C}$.

$\mathrm{CaCl}_{2} \cdot 2 \mathrm{H}_{2} \mathrm{O}(1 \mathrm{M}, 147 \mathrm{~g} / \mathrm{L})$ : filter-sterilized and stored at $4{ }^{\circ} \mathrm{C}$.

$\mathrm{KH}_{2} \mathrm{PO}_{4}(1 \mathrm{M}, 136 \mathrm{~g} / \mathrm{L})$ : filter-sterilized and stored at room temperature.

$\mathrm{K}_{2} \mathrm{HPO}_{4}(1 \mathrm{M}, 174 \mathrm{~g} / \mathrm{L})$ : filter-sterilized and stored at room temperature.

Phosphate buffer (1 M, pH 5.0): 97.5\% $1 \mathrm{M} \mathrm{KH}_{2} \mathrm{PO}_{4}, 2.5 \% 1 \mathrm{M} \mathrm{K}_{2} \mathrm{HPO}_{4}$, filtersterilized and stored at $4{ }^{\circ} \mathrm{C}$.

Phosphate buffer (1 M, pH 5.9): $90 \% 1 \mathrm{M} \mathrm{KH}_{2} \mathrm{PO}_{4}, 10 \% 1 \mathrm{M} \mathrm{K}_{2} \mathrm{HPO}_{4}$, filtersterilized and stored at $4{ }^{\circ} \mathrm{C}$.

$\mathrm{CuSO}_{4} \cdot 5 \mathrm{H}_{2} \mathrm{O}(10 \mathrm{mM}, 2.5 \mathrm{~g} / \mathrm{L})$ : filter-sterilized and stored at $4{ }^{\circ} \mathrm{C}$.

4. Carbohydrates:

Mannitol (0.4 M, $72.9 \mathrm{~g} / \mathrm{L})$ : autoclaved and stored at $4{ }^{\circ} \mathrm{C}$.

Maltose $\cdot \mathrm{H}_{2} \mathrm{O}$ ( $1 \mathrm{M}$, Sigma Grade I, $360 \mathrm{~g} / \mathrm{L}$ ): filter-sterilized and stored at room temperature.

Maltose $\cdot \mathrm{H}_{2} \mathrm{O}$ (1 M, standard quality, $360 \mathrm{~g} / \mathrm{L}$ ): filter-sterilized and stored at room temperature.

Maltose $\cdot \mathrm{H}_{2} \mathrm{O}(0.55 \mathrm{M}$, standard quality, $198 \mathrm{~g} / \mathrm{L})$ : filter-sterilized and stored at $4{ }^{\circ} \mathrm{C}$.

5. Complex organics:

KM organics $(100 \times$, Sigma K-3129): $2 \mathrm{mg} / \mathrm{L} p$-aminobenzoic acid, $200 \mathrm{mg} / \mathrm{L} \mathrm{L-}$ ascorbic acid, $1 \mathrm{mg} / \mathrm{L}$ D-biotin, $100 \mathrm{mg} / \mathrm{L}$ D-calcium pantothenate, $2 \mathrm{mg} / \mathrm{L}$ cyanocobalamin, $40 \mathrm{mg} / \mathrm{L}$ folic acid, $10 \mathrm{~g} / \mathrm{L}$ myo-inositol, $100 \mathrm{mg} / \mathrm{L}$ nicotinamide, $100 \mathrm{mg} / \mathrm{L}$ pyridoxine $\cdot \mathrm{HCl}, 1 \mathrm{mg} / \mathrm{L}$ retinol, $20 \mathrm{mg} / \mathrm{L}$ riboflavin, $100 \mathrm{mg} / \mathrm{L}$ thiamine $\cdot \mathrm{HCl}$, stored at $-20{ }^{\circ} \mathrm{C}$.

Gamborg B5 organics $(1000 \times): 100 \mathrm{mg} / \mathrm{L}$ myo-inositol, $1 \mathrm{mg} / \mathrm{L}$ nicotinic acid, $1 \mathrm{mg} / \mathrm{L}$ pyridoxine $\cdot \mathrm{HCl}, 10 \mathrm{mg} / \mathrm{L}$ thiamine $\cdot \mathrm{HCl}$, filter-sterilized and stored at $-20{ }^{\circ} \mathrm{C}$.

6. Growth regulators: 
2,4-Dichlorophenoxyacetic acid (2,4-D, $1 \mathrm{mM}): 221 \mathrm{mg} / \mathrm{L}$ dissolved in few drops of $50 \%$ ethanol by heating gently, made up to the final volume with hot $\mathrm{H}_{2} \mathrm{O}$, filter-sterilized and stored at $4{ }^{\circ} \mathrm{C}$.

6-Benzylaminopurine (BAP, $1 \mathrm{mM}$ ): $224 \mathrm{mg} / \mathrm{L}$ dissolved in $30 \mathrm{ml}$ hot $\mathrm{H}_{2} \mathrm{O}$ and 3-5 drops $1 \mathrm{M} \mathrm{NaOH}$, made up to the final volume, filter-sterilized and stored at $4{ }^{\circ} \mathrm{C}$.

7. Selective agents:

Bialaphos $(41 \mathrm{mg} / \mathrm{ml})$ : filter-sterilized and stored at $-20{ }^{\circ} \mathrm{C}$.

Spectinomycin $(100 \mathrm{mg} / \mathrm{ml})$ : filter-sterilized and stored at $-20^{\circ} \mathrm{C}$.

Tetracycline $(10 \mathrm{mg} / \mathrm{ml})$ : dissolved in few drops of $50 \%$ ethanol, filter-sterilized and stored at $-20^{\circ} \mathrm{C}$.

Timentin $(150 \mathrm{mg} / \mathrm{ml})$ : filter-sterilized and stored at $-20^{\circ} \mathrm{C}$.

8. Gelling agent:

Phytagel $(2 \times, 6 \mathrm{~g} / \mathrm{L})$ : suspended in cold water (at best $1.5 \mathrm{~g}$ Phytagel per $250 \mathrm{ml}$ unit), autoclaved and stored at room temperature.

9. Other working solutions:

Acetosyringone (1 M, $196 \mathrm{mg} / \mathrm{ml})$ : dissolved in dimethyl sulfoxide (DMSO) and stored at $-20{ }^{\circ} \mathrm{C}$.

Ethanol (70 \%): stored at room temperature.

Glycerol $(15 \% \mathrm{w} / \mathrm{v})$ : autoclaved and stored at room temperature.

L-glutamine $(37 \mathrm{mg} / \mathrm{ml})$ : dissolved by adding a few drops of $0.1 \mathrm{M} \mathrm{KOH}$ and heating in a water bath, filter-sterilized and stored at $-20{ }^{\circ} \mathrm{C}$.

Morpholinoethanesulfonic acid (MES, $212.2 \mathrm{~g} / \mathrm{L}, \mathrm{pH}$ 5.0, $\mathrm{pH}$ 5.5, and $\mathrm{pH}$ 5.9): dissolved in $40 \mathrm{ml}$ water, the $\mathrm{pH}$ adjusted with $\mathrm{KOH}$ (few pellets), stored at room temperature overnight, and the $\mathrm{pH}$ readjusted with either $1 \mathrm{M} \mathrm{KOH}$ or $1 \mathrm{M} \mathrm{HCl}$, made up to the required final volume, filter-sterilized and stored at $4{ }^{\circ} \mathrm{C}$ (see Note 1).

\subsubsection{Medium for Agrobacterium Tumefaciens}

CPY medium for A. tumefaciens strain LBA4404: $0.1 \%(\mathrm{w} / \mathrm{v})$ yeast extract, $0.5 \%$ (w/v) pancreatic peptone, $0.5 \%(\mathrm{w} / \mathrm{v})$ sucrose, $2 \mathrm{mg} / \mathrm{L} \mathrm{MgSO}_{4} \cdot 7 \mathrm{H}_{2} \mathrm{O}(\mathrm{pH} 7)$; add $1.2 \% \mathrm{w} / \mathrm{v}$ Bacto Agar to produce solid medium.

\subsubsection{Media for Plant Cell Culture}

1. Barley pollen culture (KBP) medium: $50 \mathrm{ml} / \mathrm{L} \mathrm{K}$ macro, $1 \mathrm{ml} / \mathrm{L} \mathrm{K}$ micro, $1 \mathrm{ml} / \mathrm{L}$ NaFeEDTA, $10 \mathrm{ml} / \mathrm{L} \mathrm{KM}$ organics, $12 \mathrm{ml} / \mathrm{L}$ L-glutamine, $4 \mathrm{ml} / \mathrm{L} \mathrm{BAP}$, and $250 \mathrm{ml} / \mathrm{L}$ maltose (1 M, Sigma Grade I) stocks, $\mathrm{pH}$ adjusted to 5.9 and stored at $4{ }^{\circ} \mathrm{C}$.

2. Coculture (CK) medium: $50 \mathrm{ml} / \mathrm{L} \mathrm{K}$ macro, $1 \mathrm{ml} / \mathrm{L} \mathrm{K}$ micro, $1 \mathrm{ml} / \mathrm{L} \mathrm{NaFeEDTA}$, $10 \mathrm{ml} / \mathrm{L} \mathrm{KM}$ organics, $250 \mathrm{ml} / \mathrm{L}$ maltose (1 M, Sigma Grade I), 2 ml/L BAP, 
$0.5 \mathrm{ml} / \mathrm{L}$ acetosyringone, $10 \mathrm{ml} / \mathrm{L} \mathrm{MES} \mathrm{(pH} \mathrm{5.9),} \mathrm{and} 50 \mathrm{ml} / \mathrm{L}$ phosphate buffer (pH 5.9) stocks, stored at $4{ }^{\circ} \mathrm{C}$.

3. AgroStop (ASt) medium: $50 \mathrm{ml} / \mathrm{L} \mathrm{K}$ macro, $1 \mathrm{ml} / \mathrm{L} \mathrm{K}$ micro, $1 \mathrm{ml} / \mathrm{L} \mathrm{NaFeEDTA}$, $10 \mathrm{ml} / \mathrm{L} \mathrm{KM}$ organics, $250 \mathrm{ml} / \mathrm{L}$ maltose $(1 \mathrm{M}$, Sigma Grade I), $10 \mathrm{ml} / \mathrm{L} \mathrm{MES}$ (pH 5.0), $25 \mathrm{ml} / \mathrm{L}$ phosphate buffer (pH 5.0), $7 \mathrm{ml} / \mathrm{L} \mathrm{CaCl}_{2}, 4 \mathrm{ml} / \mathrm{L}$ L-glutamine, $10 \mathrm{ml} / \mathrm{L} 2,4-\mathrm{D}, 2 \mathrm{ml} / \mathrm{L}$ BAP, $0.5 \mathrm{ml} / \mathrm{L}$ acetosyringone, $750 \mu \mathrm{L} / \mathrm{L}$ bialaphos, and $1.3 \mathrm{ml} / \mathrm{L}$ Timentin stocks, stored at $4{ }^{\circ} \mathrm{C}$.

4. Selection medium (S3): $50 \mathrm{ml} / \mathrm{L} \mathrm{K}$ macro, $1 \mathrm{ml} / \mathrm{L} \mathrm{K}$ micro, $1 \mathrm{ml} / \mathrm{L} \mathrm{NaFeEDTA}$, $10 \mathrm{ml} / \mathrm{L} \mathrm{KM}$ organics, $250 \mathrm{ml} / \mathrm{L}$ maltose (1 M, standard quality), $10 \mathrm{ml} / \mathrm{L} \mathrm{MES}$ (pH 5.5), $12 \mathrm{ml} / \mathrm{L}$ L-glutamine, $1 \mathrm{ml} / \mathrm{L}$ BAP, $750 \mu \mathrm{L} / \mathrm{L}$ bialaphos, and $1.3 \mathrm{ml} / \mathrm{L}$ Timentin stocks, stored at $4{ }^{\circ} \mathrm{C}$.

5. Solid barley pollen culture (KBP4PT) medium: $50 \mathrm{ml} / \mathrm{L} \mathrm{K}$ macro, $1 \mathrm{ml} / \mathrm{L} \mathrm{K}$ micro, $1 \mathrm{ml} / \mathrm{L}$ NaFeEDTA, $10 \mathrm{ml} / \mathrm{L} \mathrm{KM}$ organics, $250 \mathrm{ml} / \mathrm{L}$ maltose $(1 \mathrm{M}$, standard quality), $1 \mathrm{ml} / \mathrm{L}$ BAP, $12 \mathrm{ml} / \mathrm{L}$ L-glutamine, $750 \mu \mathrm{L} / \mathrm{L}$ bialaphos, and $1.3 \mathrm{ml} / \mathrm{L}$ Timentin stocks; appropriate amounts for a final volume of $0.5 \mathrm{~L}$ KBP4PT made up to an intermediate volume of $250 \mathrm{ml}$ (double concentrated), adjusted to $\mathrm{pH} 5.9$, heated to about $40{ }^{\circ} \mathrm{C}$, and then mixed (1:1) with $250 \mathrm{ml}$ Phytagel stock (melted by heating).

6. Regeneration (K4NBT) medium: $50 \mathrm{ml} / \mathrm{L} \mathrm{K} 4 \mathrm{~N}$ macro, $1 \mathrm{ml} / \mathrm{L} \mathrm{K} \mathrm{Micro,} 0.75 \mathrm{ml} /$ L NaFeEDTA, $1 \mathrm{ml} / \mathrm{L}$ B5 organics, $4 \mathrm{ml} / \mathrm{L}$ L-glutamine, $100 \mathrm{ml} / \mathrm{L}$ maltose $(1 \mathrm{M}$, standard quality), $1 \mathrm{ml} / \mathrm{L} \mathrm{BAP,} 0.49 \mathrm{ml} / \mathrm{L} \mathrm{CuSO}_{4}, 100 \mu \mathrm{L} / \mathrm{L}$ bialaphos, and $1.3 \mathrm{ml} / \mathrm{L}$ Timentin stocks; appropriate amounts for a final volume of $0.5 \mathrm{~L}$ K4NBT made up to an intermediate volume of $250 \mathrm{ml}$ (doubled concentrated), adjusted to $\mathrm{pH} 5.9$, heated to about $40{ }^{\circ} \mathrm{C}$, and then mixed (1:1) with $250 \mathrm{ml}$ Phytagel stock (melted by heating).

\subsubsection{Materials for the Isolation of Embryogenic Pollen}

1. Refrigerated centrifuge equipped with swing-out baskets

2. Waring blender (heat sterilizable)

3. Sterile Petri dishes with lid $(3.5 \mathrm{~cm}$ in diameter)

4. Sterile screw-cap polypropylene centrifuge tubes (round bottom $12 \mathrm{ml}$ and skirted conical $50 \mathrm{ml}$ tubes)

5. Magenta boxes (autoclaved)

6. Nylon mesh $(100 \mu \mathrm{m}$ grid, autoclaved)

7. Hemocytometer (type Rosenthal)

8. Filter paper disks ( $7 \mathrm{~cm}$ diameter, ash-free, autoclaved)

9. Sterile filter-stopped tips $(1 \mathrm{ml})$ for standard pipettes 


\subsubsection{Materials for Agrobacterium-Mediated Transformation}

1. Temperature-controlled incubators equipped with a rotary shaker

2. Spectrophotometer

3. Erlenmeyer flasks $(100 \mathrm{ml})$ with chicane

4. Sterile screw-cap polypropylene cryotubes $(1.5 \mathrm{ml})$

5. Sterile screw-cap polycarbonate round-bottomed tubes $(12 \mathrm{ml})$

\subsubsection{Materials for the Analysis of Transgenic Plants}

\subsubsection{Ploidy Determination and Colchicine-Induced Whole Genome Duplication}

1. Flow cytometer, e.g., Ploidy Analyser I (Partec, Münster, Germany)

2. Nylon-mesh filters, e.g., CellTrics $(30 \mu \mathrm{m}$ mesh diameter, Partec)

3. Staining buffer, e.g., CyStain UV Ploidy Staining Solution, Partec)

4. Wire brush

5. Sterile screw-cap polypropylene centrifuge conical tubes $(50 \mathrm{ml})$

6. $0.1 \% \mathrm{w} / \mathrm{v}$ colchicine, supplied with 3 drops of Tween 20 per $100 \mathrm{ml}$

\subsubsection{Molecular Analyses}

DNA Isolation, PCR, and DNA Gel Blot Analysis

1. Liquid nitrogen

2. Safe-lock tubes (1.5 and $2 \mathrm{ml})$

3. Phenol (equilibrated, stabilized)/chloroform/isoamyl alcohol 25:24:1 (AppliChem, Darmstadt, Germany)

4. Isopropyl alcohol ( $\geq 99.8 \%)$

5. Ethanol $(70 \%)$

6. Taq DNA polymerase with respective PCR buffer

7. $\mathrm{MgCl}_{2}(25 \mathrm{mM})$

8. Primers for amplification of TALEN constructs, target, and selectable marker genes:

(a) FokI-R (forward, FokI-F1 ATCGAGATCGCCCGGAACAGCACC; reverse: FokI-R1 ATCATCTCGCCGCCGATCAGGAGC)

(b) Discrimination of the left and right TALEN units (forward: ubi-F1 TTCCGCAGACGGGATCGATCTAGG; reverse: TALEN-R2 TGGCGGCTTGGCGCGTGACAG)

(c) Target gene $g f p$ (forward: GH-GFP-R2 TACGGCAAGCTGACCCTGAA; reverse: GH-GFP-F1 GGTCACGAACTCCAGCAGGA) 
(d) Selectable marker gene Bar (forward: GH-Bar-F1 GGTCTGCACCATCGTCAACC; reverse: GH-Bar-R1 TACCGGCAGGCTGAAGTCCA)

9. QIAquick PCR purification kit (Qiagen, Hilden, Germany)

10. Cloning pGEM-T vector kit (Promega, Madison, WI)

11. Agarose gel $(0.8 \%)$, freshly prepared

12. Gel electrophoresis system (Bio-Rad, Munich, Germany)

13. Positively charged nylon membrane (Hybond N+; Roche, Mannheim, Germany)

14. DIG probe synthesis kit (Roche, Mannheim, Germany)

15. DIG system for filter hybridization (Roche, Mannheim, Germany)

RNA Isolation and Reverse Transcriptase Reaction

1. TRIzol reagent (Invitrogen, Life Technologies, Darmstadt, Germany)

2. DNase I treatment kit (DNA-free kit, Ambion, Life Technologies, Darmstadt, Germany)

3. iScript Select cDNA synthesis kit (Bio-Rad, Munich, Germany)

4. Oligo $(\mathrm{dT})_{20}$ primers (Bio-Rad, Munich, Germany)

\subsection{Methods}

\subsubsection{Vector Construction and Bacterial Strains}

1. Design the gene-specific TALEN sequence pair using software tool, TAL Effector Nucleotide Targeter 2.0 (https://tale-nt.cac.cornell.edu/).

2. Evaluate the potential off-target cleavage sites in the barley genome (The International Barley Genome Sequencing Consortium, 2012) using the kmasker tool (http://webblast.ipk-gatersleben.de/kmasker/) with standard parameters.

3. Customized TALEN units can be purchased from Invitrogen (Paris, France) and delivered in standard vectors.

4. Clone the left and right TALEN units under the control of maize ubiquitin 1 promoter (Christensen and Quail 1996) and the A. tumefaciens nopaline synthase terminator using SpeI/HindIII cloning sites into pUbi-ABM destination vector (DNA Cloning Service, Hamburg, Germany).

5. Synthetic sequences encoding the Simian Virus S40 (SV40) Nuclear Localization Signal (NLS) and NLS-HA (SV40 NLS with an added hemagglutinin tag) are digested with $A s c \mathrm{I} / E c 047 \mathrm{III}$ and ligated such that the NLS becomes attached to the N-terminus of pUbi-TALEN-Left and NLS-HA to the N-terminus of pUbi-TALEN-Right. 
6. Each TALEN expression cassette is then introduced between the SfiI cloning sites of the binary vector p7d35S, which harbors Bar, a gene for bialaphos resistance, driven by the cauliflower mosaic virus doubled enhanced $35 \mathrm{~S}$ (CaMV d35S) promoter.

7. Binary vectors carrying left and right TALEN expression units are then separately introduced via electroporation into A. tumefaciens strain LBA4404/pSB1, which carries the disarmed Ti plasmid pAL4404 and the hypervirulenceconferring vector pSB1. Finally, two strains of A. tumefaciens LBA4404/pSB1 are obtained, one carrying binary vector with left and the other binary vector with right TALEN expression units.

\subsubsection{Growth of Donor Plants}

The quality of the isolated pollen cultures is strongly dependent on the conditions of the donor plants. Therefore, it is of high importance to keep the optimized conditions as described:

1. Germinate cv. "Igri" grains in a tray filled with germination substrate in a chamber providing a $12 \mathrm{~h}$ photoperiod $\left(136 \mu \mathrm{mol} \mathrm{m} \mathrm{m}^{-2} \mathrm{~s}^{-1}\right.$ photon flux density) with temperature regime of $14 / 12{ }^{\circ} \mathrm{C}$ for light/dark phases for 2 weeks.

2. Vernalize the seedlings for 8 weeks at $4{ }^{\circ} \mathrm{C}$ under an $8 \mathrm{~h}$ photoperiod.

3. After transfer to $18 \mathrm{~cm}$ diameter pots, fertilize the plants by providing $15 \mathrm{~g}$ Osmocote, and then return to the conditions described in step \#1 under Sect. 7.3.2.

4. At the tiller elongation stage, transfer the pots to a glasshouse maintained at $18 / 16{ }^{\circ} \mathrm{C}$ with a minimum of $16 \mathrm{~h}$ photoperiod $\left(170 \mu \mathrm{mol} \mathrm{m}{ }^{-2} \mathrm{~s}^{-1}\right.$ photon flux density).

\subsubsection{Isolation of Immature Pollen}

\subsubsection{Spike Pretreatment}

Harvest spikes within the boots when the awns have just emerged from the sheath of the flag leaf, surface-sterilize boots by spraying with $70 \%$ ethanol, remove the flag leaf sheath under aseptic conditions, and place the dissected spikes on a $10 \mathrm{~cm}$ diameter Petri dish (five spikes per dish) containing two moistened, $7 \mathrm{~cm}$ filter paper disks. After sealing, the plates are held at $4{ }^{\circ} \mathrm{C}$ for $4-5$ weeks in the dark.

\subsubsection{Isolation, Purification, and Pre-cultivation of Immature Pollen}

All materials coming into contact with the explant need to be sterile and precooled to $4{ }^{\circ} \mathrm{C}$, and all solutions should be kept on ice during the pollen isolation and 
purification procedures. Liquid transfer is most effectively carried out using a battery-operated pipette with filter-stopped 5 or $10 \mathrm{ml}$ pipette tips.

1. Ten to fifteen pretreated spikes are chopped into ca. $1 \mathrm{~cm}$ fragments and macerated in a blender in the presence of $20 \mathrm{ml} 0.4 \mathrm{M}$ mannitol. Usually, two bursts of $15 \mathrm{~s}$ each are performed in a Waring blender set on "low" speed.

2. The macerate is filtered through a $100 \mu \mathrm{m}$ mesh, which is placed on top of a Magenta box. The blender is flushed with $10 \mathrm{ml}$ of $0.4 \mathrm{M}$ mannitol, which is also passed through the mesh.

3. The debris remaining on the mesh is squeezed gently with tweezers, then returned to the blender for re-maceration (twice at $10 \mathrm{~s}$ ) in another $10 \mathrm{ml}$ of $0.4 \mathrm{M}$ mannitol, and the macerate passed through the mesh, which is followed by flushing the blender again with $10 \mathrm{ml}$ of $0.4 \mathrm{M}$ mannitol. The latter is also passed through the mesh.

4. The material filtered through the mesh and collected in the Magenta box is transferred to the $50 \mathrm{ml}$ centrifuge tube, and the Magenta box flushed with $5 \mathrm{ml}$ $0.4 \mathrm{M}$ mannitol, which is also added to the same tube. The suspension is centrifuged $\left(100 \times g, 10 \mathrm{~min}, 4{ }^{\circ} \mathrm{C}\right)$.

5. The pellet is resuspended in $3 \mathrm{ml} 0.55 \mathrm{M}$ maltose in a round-bottomed $12 \mathrm{ml}$ tube. The centrifuge tube is flushed with $2 \mathrm{ml} 0.4 \mathrm{M}$ mannitol, which is poured carefully over the top of the $0.55 \mathrm{M}$ maltose suspension, thereby forming two distinct liquid layers.

6. The tube containing these two layers is subjected to density gradient centrifugation in swing-out baskets $\left(100 \times g, 10 \mathrm{~min}, 4{ }^{\circ} \mathrm{C}\right)$ with the centrifuge set to give slow acceleration and deceleration so that the two layers do not become mixed. After the centrifugation step, the immature pollen is accumulated in the interphase. The interphase is withdrawn by pipetting, transferred to a fresh $50 \mathrm{ml}$ tube to which $10 \mathrm{ml} 0.4 \mathrm{M}$ mannitol is added, and resuspended with gentle shaking. $100 \mu \mathrm{L}$ aliquot of the material is placed into a hemocytometer cell to estimate the population density. Meanwhile, the remaining microspores are pelleted by centrifugation $\left(100 \times g, 10 \mathrm{~min}, 4^{\circ} \mathrm{C}\right)$. Before the supernatant is withdrawn, the tube is left at stand for ca. 5 min to allow still-floating pollen to settle down.

7. Aliquots of $1 \mathrm{ml}$ pollen suspension are transferred into $3.5 \mathrm{~cm}$ Petri dishes. The dishes are sealed with Parafilm or Nescofilm and held in the dark at $25^{\circ} \mathrm{C}$ for $7-8$ days prior to cocultivation with A. tumefaciens.

\subsubsection{Agrobacterium-Mediated Gene Transfer to Embryogenic Pollen}

\subsubsection{Preparation of A. tumefaciens Stocks}

1. As TALENs function as pairs, the left and right TALEN units are subcloned in separate binary vectors, from which two respective clones of A. tumefaciens 
strain LBA4404/pSB1 are produced. After electroporation with the selected binary vector, Agrobacterium is streaked out onto solidified CPY medium supplemented with $0.5 \mathrm{ml} / \mathrm{L}$ of tetracycline stock and $2.5 \mathrm{ml} / \mathrm{L}$ of spectinomycin stock and incubated at $28^{\circ} \mathrm{C}$ for $48 \mathrm{~h}$ (see Note 2). Single colonies are sampled using a sterile toothpick and grown overnight with shaking at $180 \mathrm{rpm}\left(28^{\circ} \mathrm{C}\right)$ in a tube containing $3 \mathrm{ml}$ liquid CPY supplemented with the respective antibiotics.

2. Plasmid DNA is isolated and the integrity of the binary vector is confirmed by restriction digest of plasmid DNA.

3. A fresh culture is initiated by adding $20 \mu \mathrm{L}$ overnight culture to $5 \mathrm{ml}$ fresh CPY medium containing antibiotics and incubating for a further $24 \mathrm{~h}$ as described above until an $\mathrm{OD}_{550}$ of approximately 2 has been reached.

4. Positive clones are grown in $10 \mathrm{ml}$ liquid CPY containing antibiotics for another $24 \mathrm{~h}$. The resulting culture is split into two $12 \mathrm{ml}$ round-bottomed tubes and centrifuged $(3.220 \times g, 12 \mathrm{~min}$, at room temperature).

5. The pellets are vortexed each in $2.5 \mathrm{ml}$ fresh CPY without antibiotics, and the suspensions are unified in one of the tubes. The cell density is adjusted by the addition of an appropriate volume of medium.

6. The cells are then mixed in an equal volume of $15 \% \mathrm{w} / \mathrm{v}$ autoclaved glycerol, and $0.5 \mathrm{ml}$ aliquots are transferred into $1.5 \mathrm{ml}$ cryotubes, left for $1 \mathrm{~h}$ at room temperature, and then stored at $-80^{\circ} \mathrm{C}$.

\subsubsection{Cocultivation of Embryogenic Pollen Cultures and A. tumefaciens}

1. A $0.5 \mathrm{ml}$ glycerol stock of a strain LBA4404/pSB1 carrying an appropriate binary vector is added to $10 \mathrm{ml}$ CPY medium containing $2.5 \mu \mathrm{L}$ spectinomycin stock and incubated at $28{ }^{\circ} \mathrm{C}$ for $24 \mathrm{~h}$ with shaking $(180 \mathrm{rpm})$.

2. The liquid cultures of each bacterial strain are split into two $12 \mathrm{ml}$ roundbottomed tubes, which are centrifuged ( $3220 \times g, 12 \mathrm{~min}$, room temperature). The pellets are vortexed each in $2.5 \mathrm{ml} \mathrm{CK}$ medium and then transferred to a $100 \mathrm{ml}$ Erlenmeyer flask, which is held at $28{ }^{\circ} \mathrm{C}$ for $1-3 \mathrm{~h}$ with shaking (100 rpm).

3. The KBP medium used to pre-cultivate the pollen is withdrawn through a $1 \mathrm{ml}$ pipette tip. This procedure is done with particular care to avoid taking up any embryogenic pollen. Then, $1 \mathrm{ml}$ of CK medium is added. It is important to minimize the time between the removal of the KBP medium and the addition of the CK medium, because microspores are rapidly damaged if they are dried.

4. One out of every ten dishes containing embryogenic pollen is left untouched to later provide a supply of feeder cells to support embryogenic development of the pollen cocultured with A. tumefaciens.

5. The A. tumefaciens cultures are diluted tenfold in water and the measured $\mathrm{OD}_{550}$ used to determine the concentration of cfu present.

6. Each $1 \mathrm{ml}$ of embryogenic pollen culture is challenged with $2.5 \times 10^{7} \mathrm{cfu}$. Immediately prior to the inoculation, the two Agrobacterium clones (one 
carrying the left and the other the right TALEN unit) are mixed in a 1:1 ratio to obtain a final cell density of $2.5 \times 10^{7}$ per $\mathrm{ml}$.

\subsubsection{Regeneration of Transgenics}

1. After $48 \mathrm{~h}$ of cocultivation, the $\mathrm{CK}$ medium is withdrawn as described above; the pollen is rinsed in $0.4 \mathrm{ml} \mathrm{ASt} \mathrm{medium,} \mathrm{taking} \mathrm{care} \mathrm{to} \mathrm{remove} \mathrm{the} \mathrm{bacterial}$ mucilage from the wall and bottom of the dish with a pipette tip (see Note 3 ). The medium is then replaced with a fresh aliquot of $1.1 \mathrm{ml} \mathrm{ASt}$, to which $100 \mu \mathrm{L}$ of non-cocultivated embryogenic pollen is added as a feeder. The sealed dishes are held in the dark at $25^{\circ} \mathrm{C}$ for 1 week with gentle shaking (75 rpm).

2. The ASt medium is replaced by $1.1 \mathrm{ml} \mathrm{S} 3$ medium (taking up any embryogenic pollen should be avoided); no washing step is required. The sealed dishes are held in the dark at $25^{\circ} \mathrm{C}$ for 1 week with shaking $(65 \mathrm{rpm})$, after which the used $\mathrm{S} 3$ medium is withdrawn and refreshed by a new aliquot of the same medium and the dishes incubated for another week.

3. Two weeks after cocultivation, the formed microcalli are transferred to an ash-free filter disk placed over solid KBP4PT medium in a $10 \mathrm{~cm}$ Petri dish. After sealing, these dishes are held in the dark at $25{ }^{\circ} \mathrm{C}$ for 2 weeks.

4. Calli that reached more than $1 \mathrm{~mm}$ in diameter can be transferred into a $10 \mathrm{~cm}$ Petri plate containing K4NBT medium, while those which have not yet reached this size can be kept for another week on KBP4PT before being transferred to regeneration medium. The sealed K4NBT plates are held in the dark at $25^{\circ} \mathrm{C}$ for 1 week and then transferred into the light.

5. After 3 weeks, the calli and any emerging regenerants are transferred to tissue culture boxes containing K4NBT and subcultured twice at 3 week intervals.

6. Regenerated plants are transferred to $6 \mathrm{~cm}$ diameter pots filled with soil substrate (Klasmann Petuniensubstrat) and placed in a tray covered by a transparent plastic hood to maintain a high-humidity environment. The tray is held in a chamber providing a $12 \mathrm{~h}$ photoperiod $\left(136 \mu \mathrm{mol} \mathrm{m} \mathrm{m}^{-2} \mathrm{~s}^{-1}\right.$ photon flux density) and a temperature regime of $14 / 12{ }^{\circ} \mathrm{C}$ for light/dark phases, respectively.

7. After 1 week, the hood is removed and the tray left uncovered for a further week. The plantlets are then vernalized for 8 weeks at $4{ }^{\circ} \mathrm{C}$ under an $8 \mathrm{~h}$ photoperiod.

8. After vernalization, the plants are grown under the conditions described for the donor plants. 


\subsubsection{Analysis of Putative Transgenic Plants}

\subsubsection{Ploidy Determination and Colchicine-Induced Whole Genome Duplication}

1. During the vernalization period, flow cytometry of leaf tissue is used to determine the ploidy level.

2. For the isolation of nuclei, a leaf sample is supplied with ice-cold staining buffer (CyStain UV Ploidy Staining Solution, Partec, Münster, Germany), and the leaf tissue is disintegrated gently with a wire brush.

3. The resulting suspension is then filtered through a nylon-mesh filter (CellTrics, $30 \mu \mathrm{m}$ mesh diameter, Partec).

4. The filtered cell suspensions of the regenerants and of controls from seedderived wild type plantlets are analyzed by a Ploidy Analyser PA I (Partec) following the manufacturer's instructions.

5. Haploids identified are exposed to a colchicine treatment after the vernalization period as follows: the soil is washed from the roots, and the tillers and roots are trimmed to a length of about $5 \mathrm{~cm}$ and $3 \mathrm{~cm}$, respectively. Each plant is placed in a $50 \mathrm{ml}$ polypropylene conical tube containing $0.1 \% \mathrm{w} / \mathrm{v}$ colchicine solution. The level of the liquid is adjusted to reach the base of the shoots. The tubes are capped and then held in the light for $6 \mathrm{~h}$ at $21^{\circ} \mathrm{C}$.

6. The plants are removed from the colchicine, and the roots carefully rinsed in water before being transferred into a $9 \mathrm{~cm}$ diameter pot filled with Petuniensubstrat. The pots are placed in a tray with a plastic hood as described above.

7. More than $80 \%$ of plantlets survive the colchicine treatment, and out of the survivors over $90 \%$ produce grain, which indicates that diploidization of germ line cells has taken place (see Note 4).

\subsubsection{Molecular Analyses}

DNA Isolation, PCR, and DNA Gel Blot Analysis

1. A $200-400 \mathrm{mg}$ sample of fresh leaf tissue is snap-frozen in liquid nitrogen.

2. DNA is isolated using the method of Palotta et al. (2000) (see Note 5).

3. PCR assays of chosen genes are performed using 50-100 ng genomic DNA as template. In this particular example, four different PCR reactions for the following templates are performed: FokI-R nuclease domain, left and right TALEN units giving amplicons of different sizes allowing for differentiation, selectable marker gene $(B a r)$, and target $g f p$ gene. All PCRs are performed in reaction volume of $20 \mu \mathrm{l}$ with the exception of $g f p$ PCR assay, where reaction volume was set to $40 \mu \mathrm{l}$.

4. The $g f p$ amplicons are subjected to purification and sequencing. Purification is performed using a QIAquick PCR purification kit (QIAGEN, Hilden, Germany) 
according to the manufacturer's instructions. Sequencing chromatograms are analyzed and aligned to the wild type sequence to see if there are differences (indels/mutations) in the targeted region.

5. The PCR products of the transgenic individuals showing chromatograms with multiple peaks after the TALEN target site, which might indicate that multiple mutated $g f p$ alleles are present among the amplicons, are cloned into pGEM-T. After blue-white selection, plasmid DNA is isolated from the positive clones and sequenced.

6. In order to determine the DNA copy number of the integrated transgene, DNA gel blot is used. For that purpose, $25 \mu \mathrm{g}$ aliquot of genomic DNA is digested overnight with suitable restriction enzymes (see Note 6). In case of the $g f p$ specific TALEN constructs, either HindIII or $S s p$ I is used. Digested DNA is electrophoresed through a $0.8 \%$ agarose gel and transferred onto a positively charged nylon membrane.

7. The nylon membrane is then hybridized with a DIG-labeled probe ( $g f p$, FokI-R, or Bar) generated from a PCR using a DIG-probe synthesis kit and the relevant primer pairs. Signal is then visualized using a DIG System for Filter Hybridization according to the manufacturer's instructions.

\section{RNA Isolation and Reverse Transcriptase Reaction}

In order to check if the integrated DNA copies are also transcribed, RNA is isolated from positive transgenic plants and reverse transcription is performed using FokI-R primers (see Note 7).

1. Leaf material is snap-frozen, ground by means of a Retsch mill, and $100 \mathrm{~g}$ powdered leaf material is used for total RNA isolation using TRIzol following the manufacturer's protocol.

2. The isolated total RNA is treated with DNase I, and then the cDNA first strand is synthesized using an iScript Select cDNA synthesis kit in the presence of oligo $(\mathrm{dT})_{20}$ primers. The resulting cDNA is used as template for subsequent PCRs based on the FokI-R domain specific primer pair (see Note 8).

\subsection{Notes}

1. A separate stock for each $\mathrm{pH}$ value $(\mathrm{pH} 5.0, \mathrm{pH} 5.5$, and $\mathrm{pH} 5.9)$ is required.

2. The disarmed Ti-plasmid pAL4404 present in LBA4404 and also the binary vectors used harbor the same spectinomycin resistance (aadA) gene. Consequently, a higher than standard concentration of spectinomycin is required $(250 \mathrm{mg} / \mathrm{L})$ to ensure the maintenance of the binary vectors. Tetracycline is used here in addition to select for Agrobacterium cells that carry the pSB1 plasmid which renders this LBA4404 derivative hypervirulent. 
3. The bacterial mucilage after removal from the wall and bottom of the dish requires to be left inside the dish, as it contains much of the embryogenic pollen.

4. As haploid plants are sterile, only the plants that underwent genome doubling set grains.

5. For molecular analyses (DNA and RNA isolation, PCR) of the transgenics, it is recommended to use filter tips because false positives are often detected due to cross contamination of samples, particularly because of the frequent use of standard marker and/or selection genes.

6. The restriction enzyme(s) used to digest the genomic DNA for gel blot analyses should cut the DNA within the inserted T-DNA but should not cleave within the gene that is used for the hybridization. In addition, the enzyme should frequently cut the genomic DNA of the investigated species, as fragments larger than $10 \mathrm{~kb}$ can be difficult to detect.

7. While working with RNA, it is extremely important to keep all equipment and materials RNase-free. Use freshly autoclaved equipment and DEPC-treated solutions.

8. DNase I treatment, cDNA first-strand synthesis, and follow-up PCR are performed according to manufacturer's instructions provided with the kit.

Acknowledgments We wish to thank Andrea Müller for her expert technical assistance. We are grateful to the Leibniz Institute of Plant Genetics and Crop Plant Research (IPK) and Gatersleben for providing our research group with excellent working conditions.

Open Access This chapter is distributed under the terms of the Creative Commons AttributionNoncommercial 2.5 License (http://creativecommons.org/licenses/by-nc/2.5/) which permits any noncommercial use, distribution, and reproduction in any medium, provided the original author (s) and source are credited.

The images or other third party material in this chapter are included in the work's Creative Commons license, unless indicated otherwise in the credit line; if such material is not included in the work's Creative Commons license and the respective action is not permitted by statutory regulation, users will need to obtain permission from the license holder to duplicate, adapt or reproduce the material.

\section{References}

Beumer KJ, Trautman JK, Christian M, et al. (2013) Comparing zinc finger nucleases and transcription activator-like effector nucleases for gene targeting in Drosophila. G3 (Bethesda) 3:1717-1725

Bitinaite J, Wah DA, Aggarwal AK, et al. (1998) FokI dimerization is required for DNA cleavage. Proc Natl Acad Sci USA 95:10570-10575

Boch J, Scholze H, Schornack S, et al. (2009) Breaking the code of DNA binding specificity of TAL-type III effectors. Science 326:1509-1512

Cermak T, Doyle EL, Christian M, et al. (2011) Efficient design and assembly of custom TALEN and other TAL effector-based constructs for DNA targeting. Nucl Acids Res 39:e82

Christensen AH, Quail PH (1996) Ubiquitin promoter-based vectors for high-level expression of selectable and/or screenable marker genes in monocotyledonous plants. Transgenic Res $5: 213-218$ 
Christian M, Cermak T, Doyle EL, et al. (2010) Targeting DNA double-strand breaks with TAL effector nucleases. Genetics 186:757-761

Christian M, Qi Y, Zhang Y, et al. (2013) Targeted mutagenesis of Arabidopsis thaliana using engineered TAL effector nucleases (TALENs). G3 (Bethesda) 3(10):1697-1705

Fichtner F, Urrea Castellanos R, Ülker B (2014) Precision genetic modifications: a new era in molecular biology and crop improvement. Planta 239:921-939

Griggs D, Stafford-Smith M, Gaffney O, et al. (2013) Policy: sustainable development goals for people and planet. Nature 495:305-307

Gurushidze M, Hensel G, Hiekel S, et al. (2014) True-breeding targeted gene knock-out in barley using designer TALE-nuclease in haploid cells. PLoS One 9:e92046

Haun W, Coffman A, Clasen BM, et al. (2014) Improved soybean oil quality by targeted mutagenesis of the fatty acid desaturase 2 gene family. Plant Biotechnol J 12:934-940

Kumlehn J, Serazetdinova L, Hensel G, et al. (2006) Genetic transformation of barley (Hordeum vulgare L.) via infection of androgenetic pollen cultures with Agrobacterium tumefaciens. Plant Biotechnol J 4:251-261

Li L, Wu LP, Chandrasegaran S (1992) Functional domains in Fok I restriction endonuclease. Proc Natl Acad Sci USA 89:4275-4279

Li T, Liu B, Spalding MH, et al. (2012) High-efficiency TALEN-based gene editing produces disease-resistant rice. Nat Biotechnol 30:390-392

Liang Z, Zhang K, Chen K, et al. (2014) Targeted mutagenesis in Zea mays using TALENs and the CRISPR/Cas system. J Genet Genom 41:63-68

Mahfouz MM, Li L, Shamimuzzaman M, et al. (2011) De novo-engineered transcription activatorlike effector (TALE) hybrid nuclease with novel DNA binding specificity creates doublestrand breaks. Proc Natl Acad Sci USA 108:2623-2628

Moscou MJ, Bogdanove AJ (2009) A simple cipher governs DNA recognition by TAL effectors. Science 326:1501

Pallotta MA, Graham RD, Langridge P, et al. (2000) RFLP mapping of manganese efficiency in barley. Theor Appl Genet 101:1100-1108

Reyon D, Tsai SQ, Khayter C, et al. (2012) FLASH assembly of TALENs for high-throughput genome editing. Nat Biotechnol 30:460-465

Shan Q, Wang Y, Chen K, et al. (2013) Rapid and efficient gene modification in rice and Brachypodium using TALENs. Mol Plant 6:1365-1368

Sun Z, Li N, Huang G, et al. (2013) Site-specific gene targeting using transcription activator-like effector (TALE)-based nuclease in Brassica oleracea. J Integr Plant Biol 55:1092-1103

Sunderland N, Roberts M, Evans LJ, et al. (1979) Multicellular pollen formation in cultured barley anthers. 1. Independent division of the generative and vegetative cells. J Exp Bot 30:1133-1144

Wang Y, Cheng X, Shan Q, et al. (2014) Simultaneous editing of three homoeoalleles in hexaploid bread wheat confers heritable resistance to powdery mildew. Nat Biotechnol 32:947-951

Waterworth WM, Drury GE, Bray CM, et al. (2011) Repairing breaks in the plant genome: the importance of keeping it together. New Phytol 192:805-822

Wendt T, Holm PB, Starker CG, et al. (2013) TAL effector nucleases induce mutations at a pre-selected location in the genome of primary barley transformants. Plant Mol Biol 83:279-285

Yang J, Yuan P, Wen D, et al. (2013) ULtiMATE system for rapid assembly of customized TAL effectors. PLoS One 8:e75649

Zhang Y, Zhang F, Li X, et al. (2013) Transcription activator-like effector nucleases enable efficient plant genome engineering. Plant Physiol 161:20-27 